NEW YORK-In no uncertain terms, a former Cellcor (Newton, MA) executive has condemned the company's kidneycancer therapy, in which a patient's $T$ cells are extracted, activated, and then reinfused into the patient. "I treated 77 patients, and none of them benefited," says Herschel Copelan, formerly the director of the Cellcor Cell Processing Center at St. Joseph Hospital Cancer Center (Orange, CA). Though Cellcor's therapy produced dramatic patient improvements in clinical trials, patients treated commercially have fared nowhere near as well.

The criticism has flattened Cellcor. Its stock has plummeted as low as $\$ 3$ a share, from a high of $\$ 12.75$ a share following its initial public offering (IPO) in March, which raised $\$ 22$ million. At least one shareholder is suing the company for misrepresentation in its IPO. And patient referrals have fallen off at its California facility, though referrals remain on track at its facilities in Atlanta, GA, and Boston, MA.

Cellcor's therapy-which costs up to $\$ 30,000$-involves two steps. First, white blood cells are collected from patients and cultured for three days with Johnson \& Johnson's (New Brunswick, NJ) OKT3 monoclonal antibody. The monoclonal activates $T$ cells, causing them to secrete cytokines like interleukins, interferons, tumor necrosisfactors, and colony stimulating factors. The culture medium is then harvested and frozen.
The second step involves treating patients once a month for six months. Each time, patient white blood cells are collected, incubated for five days with their culture medium, and then returned to the patient. Medium cytokines activate a population of $\mathrm{T}$ cells that are already primed to act against specific antigens, including tumor antigens, according to Cellcor. The company estimates that the

\section{After a former} executive trashed

\section{Cellcor's}

\section{kidney-cancer \\ therapy, its stock fell \\ to $\$ 3$, a shareholder \\ sued, and patient \\ referrals fell off.}

cytokines increase the percentage of activated $T$ cells from less than 5 percent to up to 60 percent.

\section{Theoretical therapy}

Cellcor admits that its therapy is theoretical. Whether or not $\mathrm{T}$ cells react to tumor antigens is unproven. Indeed, some scientists believe that such cells cannot act against tumor antigens since these antigens are self.

Yet Cellcor's therapy has produced dramatic patient improvements in clinical trials, without debilitating side effects. A phase III trial of 90 patients with metastatic renal cell carcinoma (RCC) showed that 45 patients who received Cellcor's therapy lived an average of 2.5 times longer than 45 patients who didn't receive the therapy. While control patients lived 8.8 months, on average, patients receiving therapy lived 21.5 months, during which time they remained "functional and productive," says Cellcor. Typically, patients with metastatic RCC-a killer of 10,000 Americans ayear-live between six and nine months.

Tumor shrinkage wasn't significant, however, with only 21 percent of the 45 patients showing such shrinkage. "This is an anomaly that doesn't fit with other cancer therapies. Survival with tumor reduction is one of the 10 commandments of oncology," says Robert Figlin, an associate professor of medicine at the University of California at Los Angeles (UCLA) School of Medicine. Cellcor's Susan Ross, vice president of clinical research, counters that the fact that tumor regression doesn't predict survival may be a "feature of immunotherapy.

\section{FDA}

The Food and Drug Administration (FDA, Bethesda, MD) doesn't regulate living-cell therapies like Cellcor's (Newton, MA) treatment of metastatic RCC, since these therapies are neither drugs nor devices. Though it is developing such regulations, FDA doesn't expect to release them for a "period of months," says an agency official. Along with Cellcor's kidney-cancer immunotherapy, other living-cell therapies include bone marrow transplants, gene therapy, the use of laboratory-grown skin, and such cell transplants as the transplant of pancreatic cells to treat diabetes.

Take bone marrow transplants, 5,000 of which were performed in the U.S. last year. FDA doesn't regulate the quality control of the transplanted cells, their dosage, donor source, or the clinical indications for the procedure. "What is the proper number of hematopoietic stem cells to be transplanted? What are the specific conditions for which transplants should be performed? What tests should be performed on the donated marrow to ensure patient safety? These are all questions FDA hasn't addressed," says Michael Osband, Cellcor's executive vice president.

Cellcor recommends a two-pronged approach to regulating living-cell therapies. A basic premise is that the actual living cells shouldn't be subject to FDA regulation, since they're viewed as an extension of the patient's body.

The first aspect would require that FDA regulate drugs and devices used to process living cells ex vivo the same way it regulates drugs and devices used in vivo. For instance, FDA would need to ap- prove a monoclonal antibody used to purge leukemic cellsfrom harvested bone marrow prior to transplant. Yet FDA would not need to approve the purged marrow, since it would be considered a living extension of the patient's body.

The second aspect would require FDA to regulate the process that prepares living cells by subjecting cell-processing facilities to registration and product listing, as well as to adherence to good manufacturing practices. A similar approach is currently used for blood banks. FDA mandates that such banks collect red blood cells through a process that standardizes cell handling, typing, labeling, storage, and safety testing. FDA assumes that cells prepared by a standard process will have the same general efficacy. "It defines the product by the process," says Cellcor's Osband. - -BJS 
Treatment may reduce the growth rate of tumor cells without eliminating them. Microscopic metastases may be eliminated as well."

Cellcor's commercial patients haven't fared as well as its clinical trial patients. Preliminary data show that the $450 \mathrm{pa}-$ tients treated commercially have survived an average of just 10 months. "The commerical patients with more severe cancer than the clinical trial patients haven't survived as long. But commerical patients with cancer severity similiar to the clinical trial patients have similiar survival rates," says Richard D'Antoni, Cellcor's chief executive officer.

\section{Pivotal trial}

An upcoming clinical trial may determine whether or not Cellcor's therapy really works. The Eastern Cooperative Oncology Group-a large network of academic oncologists-will conduct a phase III trial of 200 metastatic RCC patients that compares Cellcor's therapy to low doses of alpha interferon and interleukin-2, a treatment currently considered the best available therapy for metastatic RCC. "Cellcor will rise or fall with the trial's results," says UCLA'sFiglin, the principal investigator of the trial, which may begin later this year.

At least one Wall Street analyst still believesin Cellcor. Steve Buell of Furman Selz (New York) - the lead underwriter for Cellcor's IPO-sees the company's revenues reaching $\$ 5$ million this year, up from $\$ 1.5$ million last year. He expects Cellcor-a loser of $\$ 9.8$ million in 1991 - to break even in early 1994, with earnings reaching $\$ 1$ a share in early 1995.

Several third-party payers also believe in Cellcor. The third-party reimbursement rate for Cellcor's therapy reached 57 percent in this year's first quarter, a high rate for an expensive treatment without marketing approval from the Food and Drug Administration (FDA, Bethesda, MD). Overall, 70 insurance companies, 10 health maintenance organizations, and several state Medicare agencies have reimbursed the therapy.

But a potential partner recently lost faith in Cellcor. Cellcor and Critical Care America (CCA, Nashua, NH), a provider of out-patient care, had planned tojointly market Cellcor's therapy for metastatic RCC and, potentially, for HIV infection. CCA backed out of the deal because it was "more interested in AIDS treatment than cancer therapy," says Furman Selz's Buell. He adds, "Clearly, the loss of CCA as a partner for Cellcor is negative from the perspective of external validation by a large, experienced, and respected health-care provider."

-B.J. Spalding

WEAK THIRD QUARTER

WINDOW STILL CLOSING

NEWYORK-Asthisyear's third quarter This followed the Food and Drug ended, the record-shattering 1991/1992 Administration's (FDA, Bethesda, MD) public-financing window for U.S. bio- refusal to approve the high-profile sepsis technology companies continued to products of Centocor (Malvern, PA) and close. The quarter saw just eight compa- Xoma (Berkeley, CA), an FDA advisory nies raise $\$ 156.4$ million, a performance committee's nixing of U.S. Bioscience's similar to this year's second quarter, in (W. Conshohocken, PA) chemowhich 10 companies raised $\$ 161.1$ mil- protectant, and MGI Pharma's (Minnelion (Table 1). In comparison, 1991 and apolis, MN) halting of phase III trials of the first quarter of 1992 saw 132 compa- its chemoprotectant.

nies raise $\$ 5$ billion.

The public-financing window is closing because biotech stock prices have

This year's third-quarter offerings, for their part, included five IPOs that brought in $\$ 93.3$ million and three secondary dropped an average of 50 percent, after reaching all-time highs in January. With so many companies trading at substantial discounts to their recent highs, investors are more likely to invest in existing companies than in initial public offerings (IPOs) or even secondary offerings.

Biotech stocks
The quarter saw just eight companies raise $\$ 156.4$ million, $a$ performance similar to this year's second quarter. offerings that captured $\$ 63.1$ million. At the quarter's start, by comparison, 29 IPOs and six secondary offerings were in process. The quarter opened relatively quickly, before financing ground to a halt. In July, six companies raised $\$ 108.9$ million, while August saw two companies bring in $\$ 47.5$ million and September saw no money raised.

Indeed, several have plunged because of this year's series of setbacks. Most recently, Gensia Pharmaceuticals's (San Diego, CA) share price plummeted 38 percent, from $\$ 35.6$ to $\$ 22$, after it disclosed disappointing clinical results for its lead product, a heart-surgery drug. firms turned to private investors during the quarter. Cephalon (W. Chester, PA) raised $\$ 45$ million privately, while Arris Pharmaceutical (S. San Francisco, CA) completed a $\$ 15.5$ million private placement. -B.J. Spalding

TABLE 1. BIOTECH'S 1992 THIRD-QUARTER OFFERINGS

\begin{tabular}{|c|c|c|c|c|}
\hline Company & Target & Date & $\begin{array}{l}\text { Money } \\
\text { Raised } \\
\text { (\$ Millions) }\end{array}$ & $\begin{array}{l}\text { Post-Money } \\
\text { Valuation } \\
\text { (\$ Millions) }\end{array}$ \\
\hline \multicolumn{5}{|l|}{ Initial Public Offerings } \\
\hline British Bio-technology & Vaccines & $7 / 92$ & $\$ 57.0$ & $\$ 290.9$ \\
\hline Argus Pharmaceuticals & Cancer Therapeutics & $7 / 92$ & 11.9 & 46.2 \\
\hline Cantab Pharmaceuticals & Autoimmune Diseases & $7 / 92$ & 10.0 & 60.0 \\
\hline Envirogen & Waste Management & $8 / 92$ & 8.6 & 41.1 \\
\hline Matritech & Cancer Diagnostics & $7 / 92$ & 5.8 & 21.3 \\
\hline Subtotals & & & 93.3 & 459.5 \\
\hline \multicolumn{5}{|c|}{ Secondary Public Offerings } \\
\hline Somatogen & Blood Substitute & $8 / 92$ & 38.9 & 180.5 \\
\hline Quadra Logic Technologies & Cancer Therapeutics & $7 / 92$ & 14.2 & 84.6 \\
\hline Crop Genetics International & Engineered Plants & $7 / 92$ & 10.0 & 42.8 \\
\hline Subtotals & & & 63.1 & 307.9 \\
\hline Combined Totals & & & 156.4 & 767.4 \\
\hline
\end{tabular}

